Neoliberalism, 'race' and child welfare

\title{
Abstract
}

This article explores the significance of 'race' and ethnicity in the relationship between neoliberalism and child welfare in the UK, arguing that this has been somewhat marginal in both policy and academic discussion. It is based on a narrative review of key policy documents and research and covers a range of services from family support and child protection to looked after children and adoption. An overarching finding is that the influence of racial neoliberalism can readily be detected within a progressive downplaying of 'race' and ethnicity, emphasis on securitisation and frequent counter-offensive against 'political correctness'. Importantly, however, there have been to date limits and resistance to this influence, and the article concludes with a brief discussion of how this can be built upon.

Keywords: neoliberalism; 'race'; ethnicity; child welfare

This article seeks to explore the intersection of neoliberalism with constructions of 'race' and ethnicity as they play out in the field of child welfare in England. The past four decades or so are often depicted in terms of a growing neoliberal entrenchment and hegemony and various writers have explored its influence over social work (e.g. Garrett, 2009; Rogowski, 2012; Jones, 2015). However, within this coverage, relatively little attention has been paid to issues of 'race' and ethnicity. This is despite a strong sense of demographic change towards 'superdiversity' (Vertovec, 2007) and a shifting politics with rising anti-immigration sentiment and critique of multiculturalism. The article begins with a short overview of neoliberalism and its relationship with processes of racialization and ethnicization, before examining their workings within child and family social work. This examination will take the form of a narrative review of major policy documents and research studies in the field. 
Because of their volume, references have been cited selectively. A central concern will be to gauge the extent to which racial neoliberalism has prevailed in child and family social work.

While it has a longer history, neoliberal ideology came to prominence as a response to the economic crises of the 1970s and 1980s. As Harvey (2005) contends, the neoliberal 'revolution' can be understood in terms of class struggle, with a capitalist ruling class seeking to decisively restore profitability through weakening the power of labour and the 'protections' of the welfare state, with neoliberal attacks on 'big government' invariably a code for attacking social expenditure. Beyond desired reduction, the state was to be reconfigured along market lines, through privatisation, managerialism and the 'financialisation of everything' (Harvey, 2005).

In terms of governmentality, the crucial shift was to 'responsibilise' individuals and families, weaning them away from 'dependency' on the state, emphasising duties over rights and reframing social problems as private failings, a project to 'change souls' (Rose, 1990). Ideologically, legitimation of inequality becomes crucial for neoliberalism, both in relation to the (uber-) rich and an increasing surplus or 'disposable' population facing at best 'precarity' and often much more extreme forms of marginalisation and abjection (Standing, 2011; Tyler, 2013). Wacquant describes the neoliberal regime as a 'centaur state', presenting 'a comely and caring visage toward the middle and upper classes, and a fearsome and frowning mug toward the lower class' (2010:217). Implicitly, the neoliberal order also sought to reassert a more traditional patriarchal hierarchy, shifting as Wacquant (2010) contends from the (relatively) kindly 'nanny state' to the stricter 'daddy state'. Beyond a general 'toughening' of attitudes across welfare and penality, this would also entail rolling back concerns and provision to address inequalities. 
Although in some senses, the hegemony of neoliberalism can appear beyond dispute, it is important to remember that it has always faced considerable opposition and challenges of legitimacy (Gamble, 2001), not least due to its own internal contradictions (Harvey, 2005). This has given rise to variants such as the more socially oriented 'Third Way' of Bill Clinton and Tony Blair and alignments between neoliberalism and neoconservatism, populism and less so, libertarianism.

It is not intended here to enter the debate regarding how far neoliberalism represents an inherently racialised project (see e.g. Roberts and Mahtani, 2010; Ethnic and Racial Studies, 2013), but rather to map its racialised affinities and historical contours.

As Goldberg (2009) has argued, neoliberal thinking is characterised by a determined 'colour blindness' that conveniently ignores structural disadvantage and 'locks in' its historical legacy, a silencing that constitutes 'racism without racists' (Bonilla-Silva, 2003). Against this template, counter assertions may be made to the effect that contemporary western societies are 'post-racial' and that any lingering problems are due to those who cling/adhere to outdated modes of racial thinking (Paul, 2014).

In policy terms, this can be clearly seen in the progressive dilution, downsizing and dismantling of equality infrastructure at national and local levels (Craig, 2013). In so far as poverty and other forms of deprivation frequently take ethnicised and racialised forms, neoliberal assaults on the social state can be seen to close down potential for redistributive redress, even if in practice welfare states have often enshrined their own discriminatory practices (see e.g. Williams \& Johnson, 2010). Importantly, the shift from welfare to securitisation has had clearly racialised facets, with new forms of racism focusing on alleged abuse of welfare provision by migrants and asylum seekers and in turn, impacting on settled minority ethnic groups. However, resistance to growing inequalities has included a focus on 
racialisation within the $\mathrm{UK}$, with recent government rhetoric referring to the need to address it (May, 2016)

\section{(Children's) Social Work and Neoliberalism}

The influence of neoliberalism in child and family social work has received significant and largely critical commentary from academics and practitioners, notably in relation to changing interactions with families and marketisation or privatisation of service provision. Both universal and targeted welfare support to families have been reduced, and a more authoritarian 'shape up or face losing your children' stance taken in relation to parents (Rogowski, 2012). This thinking is facilitated conceptually by increased separation of the child from their family (Featherstone et al., 2014). Despite long established links between child welfare and poverty, this connection has been progressively erased (Parton, 2014).

What is seen as a move from therapy and welfare to surveillance and control has also intersected with forces of marketisation. This has entailed both an opening up of areas of provision to private sector providers and third sector organisations under contract and operation of remaining state activity along 'business' and managerialist lines (Harris, 2003) As Garrett (2009) contends, this agenda has followed classic neoliberal ideology, with a relentless berating of state services for 'failure' and potential solutions tied tightly to the perceived necessity for non-state 'innovation'. In recent times, the potential for private sector involvement has been extended to almost all areas of child welfare, including those relating to removal of children, although there has also been strong resistance to this (McNicholl, 2017). Beyond raising concerns over accountability (with a loss of democratic control, deregulation and the veil of 'commercial sensitivity'), it is notable that these developments marginalise both birth parents and children and young people in terms of 'voice' (Garrett, 2009; Jones, 2015). While government rhetoric tends to foreground the involvement of the 
third sector and social enterprises, in practice the direction of travel is towards services operated by large (multinational) companies and venture capitalists. Within this scenario, third sector organizations are increasingly muzzled in their critical campaigning activities because of reliance on state contracts or operating in tandem with private sector organizations (Tyler et al., 2014), leading Lavalette and Ferguson (2007: 456) to describe their role as 'the soft face of privatization'.

Neoliberalism and the (de)racialisation of child welfare

In assessing the complex intersections between neoliberalism, racialisation and child welfare, it should be noted that the evidence base is partial and sketchy and one aim of this review is to highlight where further research is needed. In each of the key areas of provision considered here, including family support, child protection and looked after children, both government guidance and relevant research will be examined. For all its obvious limitations as a guide to 'real world' practice, official guidance is nevertheless useful as a barometer of changes in governance, as particular themes arrive and depart, and are emphasised, marginalised and otherwise (re)framed.

Supporting families

Family support services (under Part III of the Children Act 1989 (CA89)) have long involved a 'safety net' function, whilst also operating in the shadow (materially and symbolically) of child protection. However, it can be argued that since the financial crash in $2007 / 8$, the tensions have sharpened, with austerity driven demand growing and capacity to respond decreased. A Community Care investigation based on Freedom of Information showed a 20 per cent rise under the coalition government in 'stopgap payments' made under section 17 of the CA89 (Carter, 2015), while the exponential rise in recourse to food banks is well known (Garthwaite, 2016). Little is known of the ethnicised pattern of this demand, but several 
studies have pointed to the disproportionately negative impact of austerity and welfare reform on certain black and minority ethnic (BME) groups (e.g. Fisher and Nandi, 2015; Runnymede Trust, 2015)

One of the hallmarks of racial neoliberalism is a bracketing out of the effects of racism, and here it is worth noting the absence of any efforts to consider the racialised effects of cuts in service provision. For example, the reduced availability of short breaks has taken place against an earlier backdrop of perceived poorer provision for BME families, yet seemingly without efforts to address racialised disadvantage or discrimination (Every Disabled Child Matters, 2015). Similarly, in children's centres - where previous research had found significant weaknesses in terms of engagement with members of minority ethnic groups and communities (Craig, 2013) - successive iterations of government guidance have placed less stress upon 'race' and ethnicity (compare e.g. DfES, 2006; DfE, 2013). While New Labour guidance on parenting and family support in 2010 emphasised context and proactivity (e.g. through community development, outreach, targeted activities and workforce diversity), subsequent coalition government pronouncements made little or no such reference (DCSF, 2010; DfE, 2013). This radical de-emphasising has also been apparent in other evaluations and commentary on the challenges facing services (see e.g. Maisey et al, 2013; 4C, 2015). With their origins in Maori culture, family group conferences (FGCs) have an obvious potential to empower BME families (and communities) in their relationships with state welfare services and to promote culturally sensitive practice. However, there is some evidence of under-representation of BME families and more broadly, a dearth of research on such families' experiences and of how far practice takes into account wider racialised contexts and structures (Barn and Das, 2016). 
In addition to retrenchment from a relatively weak base, family support services have also undergone significant change over the past two decades - being 'displaced and decentred' (Frost et al., 2015:113) by broader shifts in the terrain of state-family relations. Ideologically, the changes were framed by an emphasis on 'tough love', promoting personal and family responsibility, challenging 'welfare dependency', and 'value for money'. Within this discourse, social work became increasingly marginal and to varying degrees 'suspect' as insufficiently 'tough', despite evidence of its own toughening stances (Rogowski, 2012). Its long standing interest in prevention was progressively subsumed (and largely lost) within the more ambitious governance project of 'early intervention' initially spearheaded by the Centre for Social Justice and more recently the Early Intervention Foundation (EIF).

Early intervention policy both reflected and reinforced a sharpening focus on parenting as the key to addressing a range of social problems and facilitating social mobility. Crucially, within this mode of governance, parenting is largely decontextualised in terms of disadvantage and despite the apparent universalist appeal, classed and ethnicised underpinnings are sometimes made explicit or thinly veiled (Edwards et al., 2015) Thus, Allen and Duncan Smith contrast poor children experiencing parenting deficit with their middle class peers who 'imbibe effective social behaviour unconsciously with their mother's milk' (2008:21) and draw significantly on underclass discourses and the threat of the 'feral' (:22). Meanwhile, in a fairly obvious and crude allusion to black communities in Nottingham, Allen has attacked a dominant matriarchal culture, where the male role is often restricted to insemination (:109).

Although there are exceptions such as the Strengthening Families, Strengthening Communities programme (delivered in Britain by the Race Equality Foundation), most of the approved early intervention programmes pay little, if any attention to issues of racialised inequality. More broadly, within the academic social work domain, while early intervention 
has been subjected to substantial, sometimes trenchant critique (e.g. Featherstone et al., 2014), there has been relatively little attention paid to its ethnicised aspects.

Despite strong rhetorical support for early intervention, the coalition government made little attempt to protect its funding. Instead, attention was increasingly switched to a 'troubled families' agenda (see below), prompted particularly by the riots in summer 2011, but also building on foundations laid by their New Labour predecessors. The latter's Think Family initiative marked on the one hand, the necessity to view child welfare problems within the context of family relations, but at a macro-level signalled a shift towards the familialisation of social exclusion. Echoing earlier discourses of 'problem families' (Welshman, 2013), it identified a group of 140,000 families who were said to be suffering from multiple disadvantages in areas such as income, education, employment, health and housing, but crucially also generating (future) social problems such as crime, anti-social behaviour and NEET (Not in Employment, Education or Training) status (Cabinet Office, 2007).

The Literature Review that accompanied the launch of Think Family is exemplary in its contextualised treatment of ethnic and racial inequality (Cabinet Office Social Exclusion Task Force, 2008). It is highly nuanced in its discussion of heterogeneity within and between ethnic groups and intersections with other forms of social division, racialised and ethnicised aspects of parental mental health, substance misuse and domestic violence and interactions between service users, professionals and agencies. Such awareness is also evident, albeit somewhat diluted, within other government and related documentation for the initiative, notably in terms of targeted services, 'hard to reach' families and workforce diversity (e.g. DCSF, 2010; SCIE, 2012).

One practical manifestation of the New Labour initiative was the development of Family Intervention projects (FIP), enshrining an intensive, 'no nonsense' way of working, focused 
especially on parenting skills and the reduction of anti-social behaviour. The coalition government's Troubled Families Programme (TFP) built on this, but with a more explicit critique of social workers, with its Director General, Louise Casey referring to their frequent 'collusion' with families who needed a firmer 'getting under the skin' approach (BBC, 2013). The TFP can be located firmly within a neoliberal framework of moralisation and responsibilisation, although as was the case with FIP, frontline practice may deviate from this (Bond-Taylor, 2015; Crossley, 2016). The relationship of families from varied ethnic backgrounds to TFP is, perhaps tellingly, very unclear. For some, it has been targeted predominantly at disadvantaged white families (Crossley, 2016), with BME families underrepresented, and with a somewhat different 'less troubled' profile. Conversely, DCLG (2014) figures suggest a more nationally 'representative' division between white and BME families, though the latter are not disaggregated, nor any differences of inclusion criteria explored. Under-representation may of course, afford some advantages in terms of freedom from surveillance, but also raises important questions about availability of more supportive help.

Despite many of the problem criteria for troubled families - such as unemployment, school non-attendance, youth justice - being highly racialised, this aspect is completely marginalised, with policy documents and evaluations determinedly race-neutral and projected cost savings calculated in asocial, individualistic term. It appears that getting 'under the skin' of families does not extend to probing the significance and associations of skin colour.

\section{Child Protection}

Issues of 'race' and ethnicity have rarely been placed centrally in child protection research (Thoburn et al, 2005; Bernard and Harris, 2016). The relative neglect has been fairly consistent, as can be tracked through successive 'Messages from Research' summaries. 
Although it did contain some relevant study evidence, the 1995 overview (Department of Health (DH), 1995) acknowledged a relative lack of attention (:8). Yet in 2012, there was very little reference, and again, an acknowledgement of the need for further research (Davies and Ward, 2012:25). Similarly, two major NSPCC self-report studies both promised further analysis and reporting relating to ethnicity and child maltreatment, neither of which materialised (Cawson et al, 2002; Radford et al., 2011).

In this respect, there remains a dearth of knowledge regarding front line practice in particular. This includes the relative influences of ethnocentrism and cultural relativism (Channer and Parton, 1990). However, studies by de Waal and Shergill (2004) and BAWSO (2012) have identified a lack of confidence on the part of many social workers in addressing such issues, while it has also been noted that assessments are often poor in their coverage of 'race', ethnicity and, culture (Selwyn et al, 2010).

If it is difficult to gauge the doubtless highly variable state of front line practice, it is possible to identify a broader direction of travel in terms of signalling and scrutiny. Analysis of evolving Working Together to Safeguard Children guidance reveals a dramatic decline, bordering on disappearance, in terms of attention paid to 'race' and ethnicity. In successive iterations under New Labour (see e.g. HM Government 1999; 2010), they received wide ranging and often highly nuanced treatment. Strikingly, there was overt recognition of the significance of racism (2010:309-310) with attention paid to interactions, contexts and resources. Organisationally, safeguarding bodies were reminded of the importance of ensuring ethnic diversity within their ranks, having access to specialist advice, strong links with ethnicised communities and paying attention to issues of 'race' and ethnicity in commissioning, serious case reviews and the work of the Child Death Overview Panel (:154, 213, 239). Cultural sensitivity was also highlighted, though with the clear caveat that this cannot lead to condoning abuse through inaction (:286). 
While it should be acknowledged that this extensive coverage offered no guarantees in terms of (local) policy and practice, the lack of coverage in subsequent guidance nonetheless signals a dramatic shift. In the coalition government's guidance (HM Government, 2015a) reference to issues of 'race', ethnicity and culture has been reduced to the following brief, formulaic statement (:23):

Every assessment should reflect the unique characteristics of the child within their family and community context. The Children Act 1989 promotes the view that all children and their parents should be considered as individuals and that family structures, culture, religion, ethnic origins and other characteristics should be respected.

At first sight, it may seem that the reduction is simply a consequence of the coalition's 'slimming down' of what was widely seen as 'bloated' guidance (Parton, 2014). However, it is telling that the 2015 guidance is fairly similar in length to a 1999 predecessor which did include the more extensive treatment of 'race', ethnicity and culture outlined above. Though the rationale for such a culling was not made explicit, the revisions fit well with racial neoliberalism's tenets of individualised (in this case parental) responsibility and the 'burial' of 'race'. (With a powerful symbolism, the term racism has been expunged from the guidance).

As an Appendix to the main Working Together document, there are various links to supplementary guidance (HM Government, 2015a:106). Several of these - addressing trafficking, gangs, female genital mutilation (FGM), forced marriage, abuse linked to faith or belief (especially witchcraft and spirit possession) and radicalisation - are strongly ethnicised (including via links drawn between them). It is therefore instructive to consider how 'race' and ethnicity are addressed. In some, such as guidance on FGM, forced marriage and faithrelated abuse, there is a degree of cultural awareness and sensitivity shown, for example, 
recognising the dangers of driving practices underground, stigmatising victims and fuelling racism against particular communities (HM Government, 2016). Importantly, however, the supplementary coverage is largely de-contextualised, not least in the relationships between culture, structure and experiences of racism. As Harris (2016) notes, it is important to understand where perceived cultural practices may be reinforced in situations of social dislocation. With occasional exceptions (noted above), racism is typically framed as fear of being labelled racist for intervening and the need to resist such fear.

Immigration and Securitisation

If there is in principle 'supportive' recognition of immigration related fears and concerns for (potential) victims of FGM and forced marriage, the effectiveness of this has been questioned (Southall Black Sisters, n.d.). Yet a starker gap between theory and practice can arguably befound in relation to child trafficking. Government guidance closely follows the script set by the Borders, Citizenship and Immigration Act 2009 s55 requirement for the UK Border Agency to safeguard children's welfare. This legal change reflected earlier criticisms of the hegemonic influence of immigration law, but (subsequent) research and practitioner testimony has depicted a climate of suspicion where immigration issues still often prevail and victims may find themselves criminalised (see e.g. Pearce, 2011; Coffey, 2012; Franklin and Doyle, 2013;).

Perhaps the most obvious example of securitisation rests with social work involvement in the Prevent agenda on radicalisation (HM Government, 2015b). Government guidance and spokespersons have sought to 'normalise' such interventions as sitting clearly within the usual parameters of abuse and safeguarding, including the use of its terminology, for example grooming, and typologies (emotional, sexual abuse etc.) (Stanley and Guru, 2015). The official approach taken bears all the hallmarks of neoliberal governmentality, with a strong 
emphasis on individualisation and familialisation and of pre-emptive action based on risk (HM Government, 2015b). Critics have pointed to the vagary of concepts such as (vulnerability to) extremism and questioned the reliability and utility of assessment screening tools (Coppock and McGovern, 2014). Once again, there are obvious risks of counterproductivity in terms of individual families and perhaps more so wider (Muslim) communities (Stanley and Guru, 2015). Finally, it may be asked if 'child abuse' offers the most appropriate framework where radicalisation is suspected to be occurring or supported within families (Wheeler, 2015).

'Standing up to political correctness'

Declining attention to issues of 'race' and ethnicity has been mirrored by use of the 'political correctness' (PC) label - and the closely allied 'fear of being called racist' - to critique child protection practice, including in high profile instances such as the death of Victoria Climbié and child sexual exploitation (CSE) cases in Rochdale and Rotherham. While practice in these cases is certainly open to criticism on various grounds, the narrative of PC serves to offer a reassuring straightforward (and politically convenient) explanation for what has transpired. As Garrett (2006:320) observes, Laming's 'I don’t do political correctness when it comes to children', represents a populist caricature of professionals' practice as they deal with complex situations. In the case of CSE, arguably the most striking features are the weight of ethnicisation, and the hegemonic influence of PC narratives in both media coverage and official discourse. Within these accounts, there is little beyond a focus on the identity of perpetrators as Asian (Pakistani) men and a heavily ethnicised interpretation of their victimisation of white girls and young women (notably there is negligible focus on issues either of gender or class). Professionals and agencies, meanwhile, are portrayed alternatively as fearful, or even dogmatically unwilling, to address this ethnicised pattern, effectively allowing it impunity (HM Government, 2015c:4). 
Widely seen as authoritative, Alexis Jay's (2014) report on CSE in Rotherham, is arguably less so in relation to ethnicity. On the positive side, she avoids feeding into the ethnicised perpetrator narrative and recognises the often invisible victimisation of Asian (Pakistani) girls and young women. However, on the core 'PC' theme, the reporting on its significance is left vague. One of Jay's recommendations is that 'The issue of race should be tackled as an absolute priority if it is a significant factor..... in organised child sexual abuse..', but when discussed in the text, there is very little explanation as to what this might entail, either conceptually or practically or what might have been done differently in respect to ethnicity. As an intriguing footnote, given the earlier prominence accorded to 'race' and ethnicity in CSE by government, its most recent progress report (HM Government, 2017) paints a very positive picture of improvement, while essentially avoiding this territory.

\section{Looked After Children and Care Leavers}

Trends in policy, practice and research in respect of BME looked after children share many similarities with those in the child protection system. Analysis of evolving guidance reveals unevenness of coverage and subtle shifts, but also a clearly identifiable decline in emphasis. In relation to fostering, earlier references to the importance of ethnic matching and the need to recruit foster carers from diverse backgrounds have disappeared in later versions (see e.g.

DH, 1991; HM Government, 2011)

Similarly, children homes guidance issued to accompany new regulations in 2015 , also enshrined a markedly reduced treatment of issues of 'race' and ethnicity, with previous references to experience of marginalisation and discrimination (including for unaccompanied asylum seeking children), and integration of support for identity needs dropped (DfE, 2015). While the vulnerabilities of BME children in respect of placements, community links and 
care leavers support have previously been flagged (McDonnell et al., 2013), recent government reviews have tellingly made no mention of this (DfE, 2012a, Narey, 2016).

There has been relatively little targeted or summative research on BME looked after children or care leavers in recent years, to some extent in contrast with earlier periods (see Thoburn et al., 2005 for summary). Owen and Statham's (2009) research on disproportionality has revealed powerful ethnicised patterns in terms of placement and length of time in care. The reasons for this have to date been little explored, although recent and ongoing research by Bywaters and colleagues (2016) on child welfare inequalities in the UK will help to address this gap.

In research relating to looked after children in areas where wider ethnicised patterns are widely recognised - such as running away, school exclusions and offending - there is sometimes limited (especially intersectional) analysis within the looked after population (Coffey, 2012; Gazely et al. 2013; Schofield et al., 2014). This similarly applies to questions of unemployment, homelessness and early parenthood for care leavers (Barn, 2005; McDonnell et al., 2013). Research has also suggested that looked after BME children may find it more difficult to have effective advocacy or voices in care (Children's Society, 2011) and often feel their needs in respect of ethnicity have not been well met (HCAFCS/Coram Voice, 2015).

Unsurprisingly given their demographics, young asylum seekers have been particularly affected by tightening of immigration, and cuts in welfare provision and legal aid. Government guidance is somewhat inconsistent in tone, attempting to marry discourses of welfare, vulnerability, humanitarianism and rights, with a 'firm' stance on many being required to leave the country and the consequences of this for planning and entitlements (DfE, 2014). However, as Ayre et al. (2016) note, care leavers subject to immigration control 
are often airbrushed from official reports, including the government's Care Leaver Strategy. More importantly, perhaps, research has shown significant problems for many asylum seekers, including poor assessments, planning, and support services due to underfunding (Wade, 2011; Ayre et al., 2016).

Provision for looked after children has been at the forefront of privatisation within child social care, most notably through the rise of private children's homes as the dominant form of residential provision and the steady rise of independent (overwhelmingly private) providers now accounting for approximately 30 per cent of all placements (Ofsted, 2016). This has entailed significant market penetration by private equity companies and with their proclivity for financial restructuring, opacity and tax avoidance, this has turbo charged long standing debates on the ethics of profit-making from children's care services (Elvin, 2016). None of the debates, however, has addressed the impact of the changes for racial or ethnic (or indeed other forms of) equality. Given a paucity of recent research in this area, it is difficult to interpret this 'eerie silence'. While it would be wrong to assume that privatisation means deterioration on an already questionable level of performance, there is little reason to believe that venture capitalists will prioritise equality issues unless commissioning and financial incentives drive this. Similar arguments can be applied to financialised initiatives such as social impact bonds, where there is little evidence that they are likely to be used to promote greater racial equality (EIF, 2014).

\section{Adoption}

Amid its undeniable complexities, there is little doubt that adoption sits fairly comfortably with neoliberal governance. In particular, the narrative of bringing together children in need with loving parents has long offered privatised solutions to social problems and the prospect 
of fiscal benefits (Morgan, 1998). Within this scenario, local authorities have regularly been portrayed as obstructive of adoption, and especially so in relation to 'race' and ethnicity.

Adoption for BME children has long been one of child welfare's most controversial areas, and the core arguments surrounding support for ethnic matching and transracial adoption (TRA) will not be reprised here in any detail (see e.g. Rushton and Minnis, 1997; author's own reference, 2013). Preference for ethnic matching was endorsed in policy in the early 1990s, but growing media campaigning against its alleged 'PC' has led to progressive challenge from central government. This has involved both a playing down of the significance of ethnicity for children and tight performance management, backed by threats to remove adoption services from local authorities. While Tony Blair's review followed his predecessor in floating the idea of privatizing adoption recruitment, it did not challenge the preference for ethnic matching, emphasised the need to increase recruitment of BME families, and introduced a new legal form of permanence (later named as special guardianship), one of grounds for which was religious or cultural reservations about plenary adoption (Cabinet Office, 2000).

Within its renewed drive to increase the scale and speed of adoption, the coalition government placed tackling perceived barriers to adoption of BME children centrally (DfE, 2012b). The major legislative measure in the Children and Families Act 2014 was the removal of the 'ethnicity' clause (the requirement to consider a child's 'religious persuasion, racial origin, cultural and linguistic background' in adoption decision making). A particularly interesting feature of this process was how early coalition guidance still endorsed the preference for ethnic matching and the importance of BME recruitment, but these were progressively diluted or erased from official policy pronouncements, with recruitment explicitly dismissed by DfE officials as a solution to the problems of BME adoption (House of Lords, 2012:204). This 'disinterest' was underscored in a subsequently commissioned 
study of adoption motivations and marketing, which contained no reference to issues of ethnicity (Scott and Duncan, 2013). Also erased in the reform process was any recognition granted to special guardianship in the context of ethnicity.

The influence of racial neoliberalism is apparent in a number of ways. These include downplaying the significance of 'race' and ethnicity in the lives of children and families and in the case of special guardianship, a refusal to recognise ethnicised difference or deviation from plenary adoption. Similarly, the treatment reflects an arguably ethnocentric model of attachment, which constructs children and families as autonomous individuals outside of the ties of family and ethnicised community (Gedalof, 2013), while the (largely unquestioning) promotion of TRA fits well with the 'assimilative integration' often characteristic of racial neoliberalism (Sachrajda and Griffith, 2014). Finally, racism disappears as context, only to reappear as 'reverse racism' i.e. as discrimination against white adopters.

Crucially, the performance management regime for adoption ignores the question of ethnic matching (on which no official data have ever been collected) and the diversity of recruitment, focusing instead simply on rates and timescales for (BME) adoptions.

The broader drive to increase adoption has met with significant resistance and obstacles, both in the courts (Munby, 2013) and from academic calls for strengthened family support services (Featherstone et al, 2014). The coalition and Conservative governments have also regularly been put on the defensive by charges that their elevation of adoption as the 'gold standard' in child welfare has worked to the detriment of other permanence options which are equally worthy of support and resources. Little is known yet of the impact on adoption for BME children.

Discussion 
This article has attempted to analyse the influence of neoliberalism in the key domains of child welfare through the lens of racialisation.

It must be acknowledged that the knowledge base, particularly in relation to social work practice, is patchy - a consequence both of a paucity of research focused on racialisation and variable but often very limited coverage within 'mainstream' research. What can be clearly detected is a diminishing focus in official guidance and policy over the past two decades. This can be seen as reflecting the governmental turn away from multiculturalism towards assimilation and more culturalist explanations of the problems experienced by BME children, families and communities. Crucially, following the early impetus of the Macpherson report, there has been a discernible falling away of attention given to racism, institutional or otherwise. The increasingly 'muscular' approach is highlighted by the multiple governmental roles given to Louise Casey and Martin Narey. Unencumbered by any great sense of nuance or recognition of structural constraints, both appear happy to lead the charge against PC and the much vaunted 'fear of being called racist'.

Such a shift fits well with racial neoliberalism, although the growing focus on immigration and securitisation also attests to more populist (neoconservative) influences. In this climate, the revitalisation and reworking of anti-racist practice is challenging (Lavalette and Penketh, 2014; Williams and Graham, 2016), not least in the face of concerted efforts to depoliticise social work education and practice (Narey, 2014).

Yet it is also the case that, albeit in complex and often contradictory ways, racialised inequalities have found their way back onto political agendas, with both the current and previous Conservative Prime Ministers making strong speeches on the need to tackle them. It is of course, questionable as to how far such concerns will reach beyond rhetoric, but the latter does create a discursive space for challenge. More broadly, though it may be premature 
to refer to a demise of neoliberalism, it is undoubtedly under growing pressure, albeit from a range of political directions, Similarly, while privatisation, monetisation and marketisation have all made gains within child welfare in recent times, there is also significant resistance to this which can be built upon.

It is not the intent here, nor is there space, to set out a blueprint for challenging racial neoliberalism and its ideological affiliates, but some key points can be made drawing on the earlier analysis.

First, it remains crucial, at a time of diminished focus and silencing, to keep debates alive, in the interconnected domains of practice, research and policy development, including a reflexive ethnicisation of whiteness. Moving beyond what Phoenix (1987) has referred to as 'normalised absence and pathologised presence' is far from straightforward but cannot be achieved by playing down the significance of 'race' and ethnicity. (The Conservative government's 'vision for child social care' (DfE, 2016) makes no mention of ethnicity, other than obliquely through radicalisation.) Neither should the generalised deprivations of austerity be allowed to obscure the particularities of racialised inequalities. Second, such debates must, however, represent and enshrine sophisticated analysis, which grants the processes and products of racialisation and ethnicisation due weight, but avoids doing so in an 'essentialist' manner. Recognition of diverse ethnicised communities must equally recognise their internal heterogeneity and power dynamics. These challenges are particularly relevant to developing a more confident practice, steering between poles of neutrality and crude understandings of identity and culture. This in turn, is crucially linked to relevant research questions and findings and to policy guidance that eschews easy resolution.

Third, an important element within this work is a thorough incorporation of intersectionality, and relatedly, that critical social work engages fully with the perceived tensions between 
'identity politics' and emphasis on more class rooted formulations of inequality. A fourth factor is the urgent need to address the challenges posed by 'superdiversity' - prompted notably by more diversified migration, increases in 'mixed' relationships and changing significances attached to religion - and associated 'new' forms of exclusionary racism. Finally, in order to support these aims BME voice(s), individual and collective, must be more consistently and better heard. 
References

4Children, 2013, Children's centres census 2013: A national overview of developments in Children's Centres, London: 4Children

Allen, G and Duncan Smith, I, 2008, Early intervention: Good parents, great kids, better citizens, London: Centre for Social Justice

Ayre, D, Capron, L, Egan, H, French, A, and Gregg, L, 2016, The cost of being care free: the impact of poor financial education and removal of support on care leavers, London:

Children's Society

Barn, R, 2005, Life after care: the experiences of young people from different ethnic groups, York: Joseph Rowntree Foundation

Barn, R, and Das, C, 2016, Family group conferences and cultural competence in social work, British Journal of Social Work, 46,4, 942-959

BAWSO, 2012, Protecting black and minority ethnic children: An investigation of child protection interventions, Cardiff: BAWSO

BBC, 2013, Louise Casey: Social workers 'collude' with problem families, http://www.bbc.co.uk/news/uk-politics-23158680

Bernard, C and Harris, P, eds, 2016, Safeguarding black children: Good Practice in Child Protection, London: Jessica Kingsley

Bond-Taylor, S, 2015, Dimensions of Family Empowerment in Work with So-Called 'Troubled' Families, Social Policy and Society, 14,3, 371-384

Bonilla-Silva, E, 2003, Racism without racists: Color-Blind racism and the persistence of racial inequality in the United States, Lanham: Rowman and Littlefield 
Bywaters, P, Kwhali, J, Brady, G, Sparks, T, and Bos, G, 2016, Out of sight, out of mind: ethnic inequalities in child protection and out-of-home care intervention rates, British Journal of Social Work, 8 December

Cabinet Office, 2000, Prime Minister's review: adoption; issued for consultation; a Performance and Innovation Unit report July 2000, London: Cabinet Office

Cabinet Office, 2007, Families at risk: Background on families with multiple disadvantages, London: Cabinet Office

Cabinet Office Social Exclusion Task Force, 2008, Think family: A literature review of whole family approaches, London: Cabinet Office

Carter, R, 2015, Council spending on essential items for children in need rose $20 \%$ under coalition, Community Care, 25 November

Cawson, P, Wattam, C, Brooker, S, and Kelly, G, 2002, Child maltreatment in the United Kingdom, a study of the prevalence of child abuse and neglect, London: NSPCC

Channer, Y, and Parton, N, 1990, Racism, cultural relativism and child protection, in Violence Against Children Study Group, Taking child abuse seriously: contemporary issues in child protection theory and practice, London: Unwin Hyman

Children's Society, 2011, Advocacy services for children and young people A guide for commissioners, London: Children's Society

Coffey, A, 2012, Report From the Joint Inquiry Into Children Who Go Missing From Care https://www.gov.uk/government/uploads/system/uploads/attachment_data/file/175563/Report _-_children_who_go_missing_from_care.pdf 
Coppock, V, and McGovern, M 2014,'Dangerous minds'? deconstructing counter-terrorism discourse, radicalisation and the 'psychological vulnerability' of Muslim children and young people in Britain, Children and Society, 28,3, 242-256

Craig, G, 2013, Invisibilizing 'race' in public policy, Critical Social Policy, 33,3, 712-720

Crossley, S, 2016, Realising the (troubled) family, 'crafting the neoliberal state', Families, Relationships and Societies, 5,2, 263-279

Davies, C, and Ward, H, 2012, Safeguarding children across services: Messages from research, London: Jessica Kingsley

DCLG, (Department of Communities and Local Government), 2014, Understanding troubled families, https://www.gov.uk/government/publications/understanding-troubled-families

DCSF, 2010, Parenting and Family Support: Guidance for local authorities in England, London: DCSF

de Waal, M, and Shergill, S, 2004, Recognising and Celebrating Children's Cultural Heritage, in V White and J Harris Developing Good Practice in Children's Services. London: Jessica Kingsley

DfE (Department for Education), 2012a, Report of the Expert Group on the Quality of children's homes, presented to DfE Ministers - December 2012, London: DfE

Dfe, 2012b, An action plan for adoption: Tackling delay, London: DfE

DfE, 2013, Sure Start children's centres: Statutory guidance for local authorities, https://www.gov.uk/government/publications/sure-start-childrens-centres

DfE 2014, Care for unaccompanied and trafficked children: draft regulations and statutory guidance for local authorities on the care of unaccompanied asylum seeking and trafficked children, London: DfE 
DfE, 2015, Guide to the Children's Homes Regulations including the quality standards, London: DfE

DfE, 2016, Putting children first: Delivering our vision for excellent children's social care, London: DfE

DfES (Department for Education and Skills), 2006, Sure Start Children's Centres: Practice Guidance, London: DfES

DH (Department of Health), 1991, The Children Act 1989 Guidance and Regulations:

Volume 3 Family Placements, London: HMSO

DH, 1995, Child protection: Messages from Research, London: HMSO

Edwards, R, Gillies, V, and Horsley, N, 2015, Early intervention and evidence-based policy and practice: framing and taming, Social Policy and Society, 15,1, 1-14

EIF (Early Intervention Foundation), 2014, Introduction to social impact bonds and early intervention, London: EIF

Elvin, A, 2016, Government opposes profits from child protection - why not from care?, Community Care, 18 July

Ethnic and Racial Studies, 2013, Symposium - Rethinking Racial Formation Theory, 36,6 Every Disabled Child Matters, 2015, Short breaks in 2015: An uncertain future, London: EDCM

Featherstone, B, White, S, and Morris, K, 2014, Re-imagining child protection : Towards humane social work with families, Bristol: Policy Press

Fisher, P, and Nandi, A, 2015, Poverty across ethnic groups through recession and austerity, York: Joseph Rowntree Foundation 
Franklin, A, and Doyle, L, 2013, Still at risk: A review of support for trafficked children, London: Children's Society/Refugee Council

Frost, N, Abbott, S, and Race, T, 2015, Family support: Prevention, early intervention and early help, Cambridge: Polity Press

Gamble, A, 2001, Neo-Liberalism, Capital \& Class, 25,3 127-134

Garrett, P M, 2006, Protecting children in a globalized world: 'Race' and 'Place' in the Laming Report on the Death of Victoria Climbié, Journal of Social Work, 6,3, 315-336

Garrett, P M, 2009, Transforming children's services: social work, neoliberalism, and the modern world, Maidenhead: Open University Press

Garthwaite, K, 2016, Hunger pains: Life inside foodbank Britain, Bristol: Policy Press Gazely, L, Marrable, T, Brown, C, and Boddy, J, 2013, Reducing inequalities in school exclusion: Learning from good practice, London: Children;s Commissioner

Gedalof, I, 2013, Sameness and difference in government equality talk, Ethnic and Racial Studies, 36,1 117-135

Goldberg, D, 2009, The threat of race: Reflections on racial neoliberalism, Oxford: WileyBlackwell

Harris, J, 2003, The social work business, London: Routledge

Harris, P, 2016, Safeguarding black children from female genital mutilation, in C Bernard and P Harris (eds)

Harvey, D, 2005, A Brief History of Neoliberalism, Oxford: Oxford University Press

HCAFCS (Hadley Centre for Adoption and Foster Care Studies) /Coram Voice, 2015, Children and young people's views on being in care: a literature review, Bristol: University of Bristol 
HM Government, 1999, Working together to safeguard children: A guide to inter-agency working to safeguard and promote the welfare of children, London: Stationery Office

HM Government, 2010, Working together to safeguard children: A guide to inter-agency working to safeguard and promote the welfare of children, London: DCSF

HM Government, 2011, The Children Act 1989 Guidance and Regulations: Volume 4 Fostering Services, London: Department for Education

HM Government, 2015a, Working together to safeguard children: A guide to inter-agency working to safeguard and promote the welfare of children, London: DfE

HM Government, 2015b, Revised Prevent Duty guidance: for England and Wales, London: HM Government

HM Government, 2015c, Tackling child sexual exploitation, London: Home Office

HM Government, 2016, Multi-agency statutory guidance on female genital mutilation, Home Office/DfE/DH

HM Government, 2017, Tackling child sexual exploitation: Progress Report, London: Home Office

House of Lords, 2012a, Select Committee on Adoption Legislation: Oral and Written Evidence. http://www.parliament.uk/business/committees/committees-a-z/lordsselect/adoption-legislation-committee/publications/ Jay, A, 2014, Independent inquiry into child sexual exploitation in Rotherham 1997 - 2013, Rotheram: Rotheram Metropolitan Borough Council 
Jones, R, 2015, The end game: The marketisation and privatisation of children's social work and child protection, Critical Social Policy 35,4, 447-469

Lavalette, M, and Ferguson, I, 2007, Democratic language and neo-liberal practice: The problem with civil society, International Social Work 50,4, 447-459

Lavalette, M, and Penketh, L, (eds), 2014, Race, racism and social work: Contemporary issues and debates, Bristol: Policy Press

Maisey, R, Speight, S, and Haywood, S, 2013, Evaluation of children's centres in England (ECCE): Strand 2: Baseline survey of families using children's centres in the most disadvantaged areas: research report, London: DfE

May, T, 2016, Statement from the new Prime Minister -

https://www.gov.uk/government/speeches/statement-from-the-new-prime-minister-theresa$\underline{\text { may }}$

McNicholl, A, 2017, Government scraps controversial social care exemptions plan, Community Care, 2 March

McDonnell, S, Trevelyan, G, Smyth, J, and Lazarus, C, 2013, Action research into the more effective strategic commissioning of children's residential care homes, London: Office of the Prime Minister

Morgan, P, 1998, Adoption and the Care of Children, London: Institute of Economic Affairs Munby, J, 2013, Re B-S (Adoption: Application of s 47(5)) [2013] EWCA Civ 1146, Family Law, 43,12

Narey, M, 2014, Making the education of social workers consistently effective: report of Sir Martin Narey's independent review of the education of children's social workers, London: DfE 
Narey, M, 2016, Residential care in England. Report of Sir Martin Narey's independent review of children's residential care, London: DfE

OFSTED (2016) Children's social care data in England 2016

https://www.gov.uk/government/statistics/childrens-social-care-data-in-england-2016

Owen, C, and Statham, J, 2009, Disproportionality in child welfare: The prevalence of black and minority ethnic children within the 'looked after' and 'children in need' populations and on child protection registers in England, London: DCSF

Parton, N, 2014, The Politics of Child Protection. Contemporary developments and future directions, Basingstoke: Palgrave

Paul, J, 2014, Post-racial futures: imagining post-racialist anti-racism(s), Ethnic and Racial Studies, 37,4, 702-718

Pearce, J, 2011, Working with trafficked children and young people: complexities in practice, British Journal of Social Work, 41,8, 1424-1441

Phoenix, A, 1987, Theories of gender and black families', in G Weiner and M. Arnot, (eds) Gender under scrutiny. London: Hutchinson

Radford, L, Corral, S, Bradley, C, Fisher, H, Bassett, C, Howat, N and Collishaw, S, 2011, Child abuse and neglect in the UK today, London: NSPCC

Roberts, D, and Mahtani, M, 2010, Neoliberalizing race, racing neoliberalism: placing "race" in neoliberal discourses, Antipode, 42,2 248-257

Rogowski, S, 2012 Social work with children and families: challenges and possibilities in the neo-liberal world, British Journal of Social Work, 42,5, 921-940

Rose, N, 1990, Governing the soul: The shaping of the private self, London: Routledge 
Runnymede Trust, 2015, The 2015 Budget: Effects on black and minority ethnic people http://www.runnymedetrust.org/projects-and-publications/employment-3/budget-2015impact-on-bme-families.html

Rushton, A, and Minnis, H, 1997, Annotation: transracial family placements, Journal of Child Psychology and Psychiatry, 38,2, 147-159

Sachrajda, A and Griffith, P, 2014 Shared Ground: Strategies for Living Well Together in an Era of High Immigration, London: IPPR

SCIE (Social Care Institute for Excellence, 2012, Think child, think parent, think family: Final evaluation report, London: SCIE

Schofield, G, Biggart, L, Ward, E, Scaife, V, Dodsworth, J, Haynes, A, and Larsson, B, 2014, Looked after children and offending: Reducing risk and promoting resilience, London: British Association for Adoption and Fostering

Scott, A, and Duncan, C, 2013, Understanding attitudes, motivations and barriers to adoption and fostering, London: Kindred

Selwyn, J, Quinton, D, Harris, P. Wijedasa, D, Nawaz, S, and Wood, M, 2010, Pathways to Permanence for Black, Asian and Mixed Ethnicity Children. London: British Association for Adoption and Fostering

Southall Black Sisters, The forced marriage Campaign, http://www.southallblacksisters.org.uk/campaigns/forced-marriage-campaign

Standing, G, 2011, The precariat: The new dangerous class, London: Bloomsbury

Stanley, T, and Guru, S, 2015, Childhood radicalisation risk: An emerging practice issue, Practice: Social Work in Action, 16 June 
Thoburn, J, Chand, A, and Procter, J, 2005, Child welfare services for minority ethnic families: The research reviewed, London: Jessica Kingsley

Tyler, I, 2013, Revolting subjects: Social abjection and resistance in neoliberal Britain, London: Zed books

Tyler, I, Gill, N, Conlon, D, and Oeppen, C, 2014, The business of child detention: Charitable co-option, migrant advocacy and activist outrage, Race and Class, 56,1, 3-21

Vertovec, S, 2007, Super-diversity and its implications, Ethnic and Racial Studies, 30,6, $1024-1054$

Wacquant, L, 2010, Crafting the neoliberal state: workfare, prisonfare, and social insecurity, Sociological Forum, 25,2 197-220

Wade, J, 2011, Preparation and transition planning for unaccompanied asylum-seeking and refugee young people: A review of evidence in England, Children and Youth Services Review, 33,12, 2424-2430

Welshman, J, 2013 Underclass: A history of the excluded since 1880, London: Bloomsbury Wheeler, M, 2015 Radicalism and the Family Courts, UK Human Rights Blog, https://ukhumanrightsblog.com/2015/10/30/radicalism-and-the-family-courts-marina$\underline{\text { wheeler/ }}$

Williams, C, and Johnson, M, 2010, Race and ethnicity in a welfare society, Maidenhead: Open University Press

Williams, C, and Graham, M, (eds) 2016, Social work in a diverse society: Transformative practice with black and minority ethnic individuals and communities, Bristol: Policy Press 
The author declares there is no conflict of interest. 